Marquette University

e-Publications@Marquette

Social and Cultural Sciences Faculty Research and

Publications

Social and Cultural Sciences, Department of

$2-1-2012$

\title{
Narrative Practice and the Transformation of Interview Subjectivity
}

Jaber F. Gubrium

University of Missouri - Kansas City

James A. Holstein

Marquette University, james.holstein@marquette.edu

Published Version. 'Narrative Practice and the Transformation of Interview Subjectivity' in The SAGE Handbook of Interview Research: The Complexity of the Craft Second Edition. Eds. Jaber F. Gubrium, James A. Holstein, Amir B. Marvasti, and Karyn D. McKinney. SAGE Publications (2012): 27-43. Permalink. (C) 2012 Sage Publications. Used with permission. 


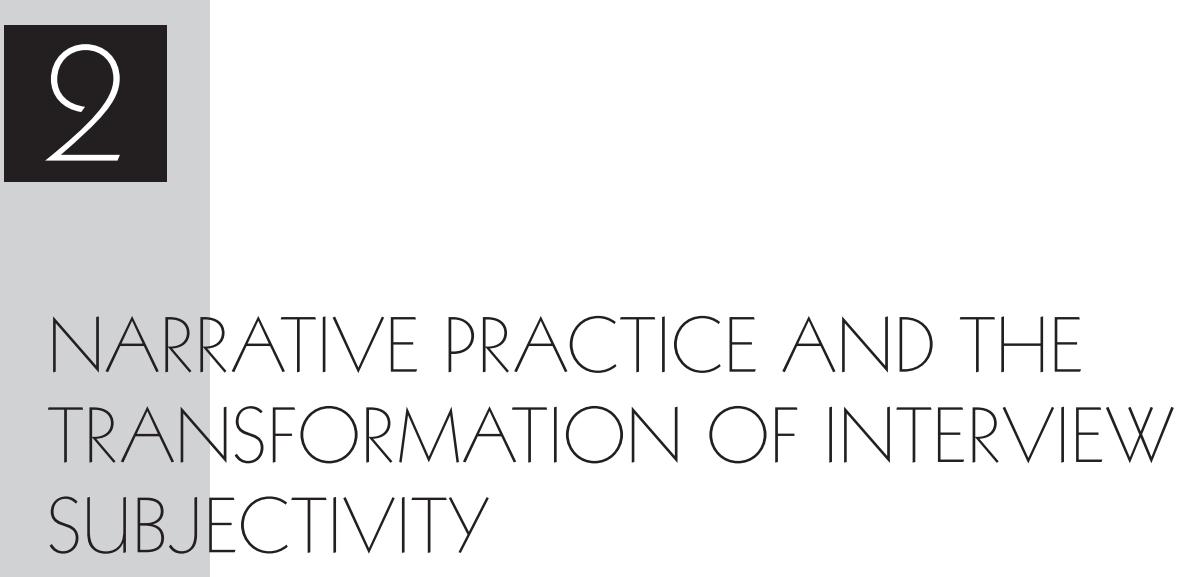

\section{- Jaber F. Gubrium and James A. Holstein}

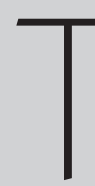
he research interview was once viewed as a straightforward method of data collection. Respondents were contacted, interviews scheduled, a location determined, ground rules set, and the interviews begun. Questions were designed to elicit answers in an anticipatable form from respondents until interview protocols were complete. The respondent's job was to provide information pertinent to the research project. Knowing his or her role, the respondent waited until the questions were posed before answering. Duties did not extend to managing the encounter or raising queries of his or her own. This was the interviewer's responsibility. If the respondent asked questions, they were treated as requests for clarification.

This model of the interview informed social research for decades. Most people are now well acquainted with what it takes to play either role, recognize what it means to interview someone, and broadly know the aims of the interview process.
The requirements of interviewing are familiar, whether they take the form of demographic questionnaires, product use surveys, Internet polls, or health inventories. The roles and expectations cross the borders of scientific and professional interviewing.

Recently, researchers have begun to scrutinize the traditional model's epistemological bearings (see, e.g., Denzin \& Lincoln, 2005, 2011). A more reflexive appreciation of knowledge production in general, not just interview knowledge, has prompted a reassessment of the procedures of empirical inquiry, including the interview. Given its centrality in a recent turn toward more sophisticated analyses of knowledge production (see Chase, 2011), the interview can no longer be viewed as a unilaterally guided means of excavating information. It is being reevaluated in terms of its structure, interactional dynamics, situational responsiveness, and discursive dimensions. 
This chapter discusses the transformation of how researchers conceive of respondent and interview roles, the nature of interview information, and the relationship of the information to society. These themes are traced through critical commentary on models of interview subjectivity and their relation to narrative practice in the interview context. Reconceptualizing interview roles in terms of narrative practice presents a more active version of how interview participants actually operate. Their agency is recast as artful, collaborative, and suffused with discourse. If the responsive, yet relatively passive, respondent and the inquiring interviewer once characterized participant subjectivity, this is now considered deceptively simple. It has given way to a more interactionally sensitive and constructive perspective, featuring the active narrativity of the enterprise. The chapter explores the implications of this transformation for how interview data might be construed and analyzed.

\section{- Public Opinion and Surveillance}

Despite its familiarity, the interview is a relatively recent phenomenon and was once figured to be strange in the everyday scheme of things. As a systematic method for obtaining experiential knowledge, it is the product of a mere century of development (Platt, 2002). Undergirding the emergence of the interview was a new understanding that the individual person - each and every one of themis an important source of knowledge. We can imagine, of course, that questioning and answering have been with us since the beginning of communication. As long as we have had parental authority, parents have questioned their children regarding their whereabouts and activities. Similarly, suspects and prisoners have been interrogated since suspicion and incarceration have been a part of human affairs. Healers, priests, employers, writers, and many others seeking knowledge about daily life for practical purposes have all engaged in interview-like inquiry.

Yet a century ago, it would have seemed peculiar for a complete stranger to approach us-any one of us, from the humblest to the most celebrated-and to ask for permission to discuss personal matters just for the sake of knowledge. Questioning and answering was more practical. Daily life was, in many ways, more intimate; everyday affairs were conducted on a face-to-face basis only between those well acquainted with each other. According to Mark Benney and Everett Hughes (1956), "The interview [as a behavioral format] is a relatively new kind of encounter in the history of human relations" (p. 193). It is not the asking and answering of questions that was new. Rather, the innovation was a preplanned conversation between strangers from all walks of life devoted to information gathering without an immediate purpose in view (Benney \& Hughes, 1956).

Especially after World War II, with the emergence of standardized survey interviews, individuals became accustomed to offering their opinions for the sake of information gathering. "Public opinion" became a newfound and anonymous forum within which individuals could forthrightly express their most private thoughts and deepest feelings with the expectation that their published opinions were anonymous but important. No matter how insignificant their station in life, they were treated as equal elements of populations of interest. Each person had a voice, and it was imperative that each voice be heard. Seeking the gamut of thoughts and sentiments, the research interview democratized opinion.

\section{THE MODERN TEMPER}

Guided by the new "modern temper," the times progressively embraced routine conversational exchanges between strangers (Riesman \& Benney, 1956). When they encountered an interview situation, people weren't immediately defensive about being asked for information about their lives, their associates, and even their heartfelt sentiments. They readily recognized and accepted two new roles associated with talking about oneself and one's life to strangers, (1) the role of interviewer and (2) the role of respondent, the centerpieces of the now familiar interview encounter.

Interviewing helped spread the understanding that all individuals have the wherewithal to offer a meaningful description of, or a set of opinions about, their lives. Experiential knowledge was no longer the principal responsibility of high-status commentators-of tribal chiefs, village headmen, or the educated classes-who in other times and places spoke for one and all. As Pertti Alasuutari (1998) explains, it wasn't so long ago that when one wanted to know something important about society or daily life, one asked those allegedly "in the know" 
(also see Platt, 2002). In contrast to what seems selfevident today - that is, questioning those individuals whose experiences are under consideration-the obvious and efficient choice was to ask informed citizens to provide answers to research questions. Those considered to be properly knowledgeable in the subject matter, Alasuutari notes, were viewed as informants. Not everyone's opinion counted, certainly not the opinions of the "humbler classes" (see Mayhew, 1851, pp. xv-xvi). But the modern interview changed this, giving rise to the importance of all opinion. (See, e.g., the proliferation of Internet interviews and surveys that derive entertainment value from the valorization of any and all publicly offered opinions.)

\section{BIOPOLITICS}

Along with the democratization of opinion came increasing life surveillance, what Michel Foucault (Dreyfus \& Rabinow, 1982) calls "biopolitics." The survey interview became an efficient means of information gathering for populations of individuals. Foucault's (1973, 1975, 1977, 1978) seminal studies of the discursive organization of identity shed important light on the development of individualized subjectivity. Time and again, in institutional contexts ranging from the medical clinic and the mental asylum to the prison, Foucault showed how "technologies of the self" created and transformed sources of information about who and what we are (see Dreyfus \& Rabinow, 1982; Foucault, 1988). The phrase refers to the concrete practices through which a sense of, and information about, individual identity is constructed. The notion that each and every one of us has an ordinary self, capable of reflecting on his or her experience, individually describing it, and communicating opinions about it and his or her surrounding world, created a new subjectivity worth communicating about.

The technologies Foucault especially had in view were the concrete, socially and historically located institutional practices, including individual interviews, through which the new democratic and individualized sense of who and what we are as human beings was being constructed. Prompted, this individualized subject would duly offer his or her outlook and sentiments within the self-scrutinizing regimens of what Foucault (1991) called "governmentality," the unwitting archipelago of surveillance practices suffusing modern life. As James Miller (1993, p. 299) points out, governmentality extends well beyond the political and carceral, to include pedagogical, spiritual, and religious dimensions (also see Garland, 1997). If Bentham's original panopticon was an efficient form of prison surveillance, panopticism in the modern temper became the widespread self-scrutiny that "governs" all aspects of life in the very commonplace questions and answers we continually apply to ourselves both in our inner thoughts and in public inquiries. Now formalized in opinion surveys and increasingly in media interviews, these are inquiries about what we personally think and feel about every conceivable topic, including our most private actions.

The research interview was a constitutive part of this development. Indeed, this interview may be seen as one of the 20th century's most distinctive technologies of the self. It helped scientize the individualized self. As Nikolas Rose $(1990,1997)$ has shown in the context of the psychological sciences, the shaping of the private self, along with its descriptive data, was invented right along with the technologies we now associate with behavioral and attitude measurement. Scientific surveillance such as psychological testing, case assessments, and individual interviews of all kinds have created the experiencing and informing respondent we take for granted as the subject of our inquiries.

\section{LEARNING FROM STRANGERS}

The title of Robert Weiss's (1994) popular how-to book on interviewing, Learning from Strangers, affirms the importance of anonymous opinion seeking. Behind each bit of advice on how to interview effectively is the understanding that every strangerrespondent one encounters as an interviewer is someone worth listening to. The respondent is someone who can provide amazingly detailed descriptions of his or her thoughts, feelings, and activitiespresumably better than anyone else-if one asks and listens carefully. The trick, in Weiss's judgment, is to present a concerned attitude, expressed within a wellplanned and encouraging format. The aim is to derive as objectively as possible the respondent's own opinions on the subject matter, opinions that will readily be offered up and elaborated on by the respondent when circumstances are conducive to doing so and the proper solicitations extended. 
The full range of individual experiences is accessible through interviewing, according to Weiss (1994), because the interview is a virtual window on experience. It is its own panopticon. In answering the question of why we interview, Weiss offers a compelling portrayal of the democratization of experiential knowledge:

Interviewing gives us access to the observations of others. Through interviewing we can learn about places we have not been and could not go and about settings in which we have not lived. If we have the right informants, we can learn about the quality of neighborhoods or what happens in families or how organizations set their goals. Interviewing can inform us about the nature of social life. We can learn about the work of occupations and how people fashion careers, about cultures and the values they sponsor, and about the challenges people confront as they lead their lives.

We can learn also, through interviewing, about people's interior experiences. We can learn what people perceived and how they interpreted their perceptions. We can learn how events affect their thoughts and feelings. We can learn the meanings to them of their relationships, their families, their work, and their selves. We can learn about all the experiences, from joy through grief, that together constitute the human condition. (p. 1)

\section{$\checkmark$ The Interview Society}

Today, interviewing is ubiquitous. Think of how much is learned about people and their experiences by way of interviews, across a broad spectrum of venues and beyond the realm of social research. Interviews, for example, are an important source of celebrity, notoriety, and entertainment. News media interviewers introduce us to presidents and power brokers, who not only provide a mass audience with their thoughts, feelings, policies, and opinions but also cultivate fame in the process. The process implicates the deepest secrets and sentiments, not just the political, economic, or social savvy of high-profile figures. Interviewers like Barbara Walters or Oprah Winfrey plumb the emotional depths of luminaries and VIPs from across the political and entertainment gamut. To this, add television talk show hosts of all stripes, who daily invite ordinary men and women, the emotionally tortured, and the behaviorally bizarre to "spill their guts" to millions. Questions and answers fly back and forth on the Internet, where blogs, chat rooms, Facebook, and Twitter are as inquisitive and intimate as back porches, bars, and bedrooms. The interview is a premier experiential conduit of the electronic age.

Interviews extend to professional realms as well. Countless institutions employ interviewing to generate useful and often crucial information. Physicians conduct medical interviews with their patients to formulate diagnoses and monitor progress in treatment (see Zoppi \& Epstein, 2002). Employers interview job applicants, guided by consultants who formularize the process (see Latham \& Millman, 2002). Psychotherapy always has been a largely interview-based human service, perhaps more diversified in its perspectives than any other professional interviewing (see Miller, de Shazer, \& De Jong, 2002). Even forensic investigation has come a long way from the interview practices of the Inquisition, where giving the "third degree" was the last resort of interrogation (see McKenzie, 2002).

As interviewing became pervasive, an interviewing industry developed. Survey research, public opinion polling, and marketing research are in the vanguard. This crosses over as survey research is increasingly employed for commercial purposes. The interviewing industry now extends from individual product use inquiries to group-interviewing services, where focus groups are used to quickly establish everything from consumer product evaluations to voter preferences (see Morgan, 2002).

David Silverman $(1993,1997)$ argues that we live in an "interview society," in which interviews are central to making sense of life (see Gubrium \& Holstein, 2002). The interview process and the interview society are reflexively related, the process giving discursive shape to the social form and the social form prompting us to present who and what we are writ large in its terms. Resonating with the modern temper and governmentality, Silverman (1997) identifies three requisite conditions for this development. First, the interview society requires a particular form of informing subjectivity, "the emergence of the self as a proper object of narration" (p. 248). Second, there is a need for the "technology of the confessional." The interview society requires a procedure for securing the narrative by-product of "confession," which, as Silverman points out, extends 
not only to "friend[ship] with the policeman, but with the priest, the teacher, and the 'psy' professional" (p. 248). Third, and perhaps most important, a mass technology must be widely available and easily accessible. The interviewing ethos and its technical realization must be recognizably in place throughout society, so that virtually everyone is familiar with the goals of interviewing as well as what it takes to participate in an interview.

Not only do communications media and human service professionals get their information from interviews, but it's been estimated that fully $90 \%$ of all social science investigations exploit interview data (Briggs, 1986). Internet surveys now provide instant questions and answers about every imaginable subject; we are asked for our inclinations and opinions regarding everything from political candidates to suggestions for which characters on TV serials should be retained or removed. The interview society is a contemporary fixture, flourishing as a leading milieu for addressing the subjective contours of daily living.

The prominence of the interview has served to promote the individualized subject (Atkinson \& Silverman, 1997) as a key feature of the interview society. Ultimately, there is a fundamentally romantic impulse undergirding the interview enterprise. If we desire to really know the individual subject, then we must provide a means of hearing his or her authentic voice. "Really," "authentic," and "voice" are the bywords. Superficial inquiry and description are inadequate. Accordingly, interviewers are prompted to explore the deeper emotional grounds of the self by way of open-ended or in-depth interviewing. While, technically, these are merely alternative ways of structuring the interview process, Atkinson and Silverman (1997) argue that the words flag an epistemological understanding, namely, that the true voice of the subject is internal and comes through only when it is not externally screened or otherwise narratively fettered. The interview society, it seems, is the province of subjects harboring deep inner meanings, selves, and sentiments, whose stories retain the truths of the matters in question.

But Atkinson and Silverman (1997) caution that authenticity should not be taken as ultimate experiential truth. Authenticity itself is a methodically constructed product of communicative practice (see Gubrium \& Holstein, 2009b). Authenticity has a constructive technology of its own, in other words. Recognizable signs of emotional expression and scenic practices such as direct eye contact and intimate gestures are widely taken to reveal deep truths about individual experience (also see Gubrium \& Holstein, 1997, 2009a; Holstein \& Gubrium, 2000). We "do" deep, authentic experiences as much as we "do" opinion offering in the course of the interview. It is not simply a matter of procedure or the richness of data that turns researchers, the interview society, and its truth-seeking audiences to in-depth and open-ended interviewing. Rather, discursive conventions make audible and visible the phenomenal depths of the individual subject.

\section{$\checkmark$ The Turn to Narrative Practice}

If experience is increasingly generated and mediated by the interview, everyday reality is also becoming even more narratively formulated. As Charles Briggs (2007) puts it, interview narratives "produce subjects, texts, knowledge, and authority" (p. 552). As part of a recent narrative turn, social researchers aim to document and understand the discursive complexity of narratives of all sorts (see Chase 2005, 2011; Gubrium \& Holstein, 2009a; Hyvärinen, 2008; Polkinghorne, 1988, 1995; Riessman, 2008). Texts and textual analysis have become de rigueur in the social sciences. Briggs and many others are especially interested in how interviews and their stories are assembled and communicated and how they circulate in various domains of society. The diversity is stunning, as particulars are worked up and presented in specific settings, performing different functions and having varied consequences.

Most researchers acknowledge the interactional bases of interviewing (see Conrad \& Schober, 2008; Warren \& Karner, 2005), but the technical literature typically stresses the need to keep conversational bias in check. Guides to interviewing-especially those oriented to standardized surveys-are primarily concerned with maximizing the flow of valid, reliable information while minimizing distortions of what the respondent knows (Fowler \& Mangione, 1990; Gorden, 1987). But a heightened sensitivity to the constitutive properties of communication-characteristic of poststructuralist, postmodernist, constructionist, and ethnomethodological inquiry-has refocused attention on the in situ activeness of interviews (e.g., Hootkoop-Steenstra, 2000; Kvale, 1996). These perspectives view meaning as socially 
constituted; experience is the product of the actions undertaken to produce and understand it (see Cicourel, 1964, 1974; Garfinkel, 1967). Treating interviewing as a social encounter in which knowledge is actively formed and shaped implies that the interview is not so much a neutral conduit or source of distortion as an occasion for constructing accounts (Gubrium \& Holstein, 1995; Holstein \& Gubrium, 1995; see Warren \& Karner, 2005).

Briggs (1986) explains that the social circumstances of interviews are more than obstacles to respondents' articulations. Interview situations fundamentally, not incidentally, shape the form and content of what is said. Interviews result in locally pertinent narrativessome longer than others-that represent versions of opinion, persons, events, and the world at large. The circumstances of narrative production are deeply and unavoidably implicated in creating the meanings that ostensibly reside within individual experience. Meaning is not merely directly elicited by skillful questioning, nor is it simply transported through truthful replies; it is strategically assembled in the interview process (Holstein \& Gubrium, 1995). Interview participants are as much constructive practitioners of experiential information as they are repositories or excavators of experiential knowledge.

This view reconceptualizes interviews in terms of narrative practice. It suggests the need to concertedly attend to the meaning-making work and communicative conditions of interviewing (Gubrium \& Holstein, 2009a). In this context, researchers pay explicit attention to both the constructive hows and the substantive whats of interviewing, taking care to give them equal status both in the research process and in reporting results (see Gubrium \& Holstein, 1997, 2009a). Understanding how the narrative process constructively unfolds in the interview is as critical as appreciating what is selectively composed and preferred.

The new understanding, in turn, prompts a reimagining of the subjects behind interview participants. Regardless of the type of interview, there is always a model of the subject lurking behind those assigned the roles of interviewer and respondent (Holstein \& Gubrium, 1995). Even the soberly rational and controlled survey interview has an implicit subjectivity. By virtue of the subjectivity we project-again regardless of the type of interview-we confer varying senses of agency on interviewers and respondents. Differential methodological sensibilities ensue.

\section{PASSIVE SUBJECTIVITY}

Recent developments in research interviewing have begun to transform interview subjectivity from fundamentally passive to concertedly and constructively active. In traditional interviewing, respondents are envisioned as being vessels of answers to whom interviewers direct their questions. Respondents are seen as repositories of facts, reflections, opinions, and other traces of experience. This extends to nonresearch interviews. Studs Terkel, journalistic interviewer par excellence, worked with the traditional image in place. He simply turned on his tape recorder and asked people to talk. Writing of the interviews he did for his book Working, Terkel (1972) explained,

There were questions, of course. But they were casual in nature ... the kind you would ask while having a drink with someone; the kind he would ask you.... In short, it was a conversation. In time, the sluice gates of dammed up hurts and dreams were open. (p. xxv)

Others have likened traditional interviewing to "prospecting" for the true facts and feelings residing within the respondent (cf. Kvale, 1996). The image of prospecting turns the interview into a search-anddiscovery mission, with the interviewer intent on detecting what is already there within more or less cooperative respondents. The challenge lies in excavating information as efficiently as possible, without contaminating it. Highly refined interview techniques streamline, systematize, and sanitize the process. Occasionally, researchers acknowledge that it may be difficult to obtain accurate or honest information, but the information is still imagined, in principle, as embedded in the respondent's vessel of answers. The challenge is to formulate reliable questions and provide an atmosphere conducive to open communication between interviewer and respondent. The challenge is all up-front, in recalcitrant respondents and feckless interviewers, not in the vessel of answers.

In the vessel-of-answers approach, the image of the subject behind the respondent is passive, even while the subject's respondent may be actively reluctant or otherwise difficult to deal with (see Adler \& Adler, 2002). The subjects themselves are not engaged in the production of knowledge. If the interviewing process goes "by the book" and is nondirective and unbiased, respondents will validly and 
reliably speak the unadulterated facts of experience. Contamination creeps in from the interview setting, its participants, and their interaction; the imagined subject, in contrast, is pristinely communicative, and under ideal conditions, his or her respondent serves up authentic reports when beckoned.

Much of the traditional methodological literature on interviewing deals with the nuances of aligning respondents with a passive subjectivity. Understandably, the vessel-of-answers view leads interviewers to be careful in how they ask questions, lest their method of inquiry bias what lies within the subject. This has prompted the development of myriad procedures for obtaining unadulterated information, most of which rely on interviewer and question neutrality. Successfully implementing neutral practices elicits truths held uncontaminated in this vessel of answers. "Good data" result from the successful application of these techniques.

This image evokes a complementary model of the subject behind the interviewer. Because the interviewer aims to extract information, he or she stands apart from the actual data; the interviewer merely unearths and collects what is already there. Interviewers are expected to avoid shaping the information they extract. This involves controlling one's opinions as an interviewer so as not to influence what the passive interview subject can communicate. Interviewers resist supplying particular frames of reference or personal information in the interview. Interviewers are expected to keep themselves and their preferences out of the interview conversation. Neutrality is the standard. Ideally, the interviewer uses his or her interpersonal skills to merely encourage the expression of, but not help construct, the attitudes, sentiments, and behaviors under consideration. The ideal interviewer is a facilitator, not a coproducer, of pertinent information. This stance relegates the interviewer's involvement in the interview to a preordained role, one that is constant from one interview to another. Should the interviewer introduce anything other than variations on prespecified questions, the generalizability of the interview is compromised. This is understandable given the subjectivity in place.

\section{ACTIVE SUBJECTIVITY}

Drawing on a contrasting image of active subjectivity, interview researchers are increasingly appreciating the narrative agency of the subjects behind the participants, of both respondents and interviewers. Interviews have been reconceptualized as formal occasions on which animated subjects collaboratively assemble accounts of experience (see Holstein \& Gubrium, 1995). Conceiving the interview in this way casts participants as constructive practitioners of the enterprise, who work together to discern and designate the recognizable and orderly features of the experience under consideration (see Bamberg, 2006; Chase, 2011; Clandinin, 2007; Gubrium \& Holstein, 2009a; Riessman, 2008).

This transforms the subject behind the respondent from a repository of information or wellspring of emotions into an animated, productive source of narrative knowledge (see Polkinghorne, 1988). The subject behind the respondent not only retains the details of his or her inner life and social world but, in the very process of offering them up to the interviewer, stories the information, assembling it into a coherent account (see Linde, 1993). The respondent can hardly spoil what is subjectively constructed in the first place. Indeed, the active subject pieces experience together before, during, and after occupying the respondent role. He or she is, in a phrase, "always already" a storyteller.

Active subjectivity also lurks behind the interviewer. His or her participation in the interview process is not ultimately a matter of standardization or constraint; neutrality is not the issue. One cannot very well taint the solicitation of knowledge if its response expectations do not exist in some pure form apart from the process of communication. Rather, the active subject behind the interviewer is a necessary counterpart, a working narrative partner, of the active subject behind the respondent. The subject behind the interviewer is fully engaged in the coproduction of accounts. From the time one identifies a research topic, to respondent selection, questioning and answering, and, finally, to the interpretation of responses, the interviewing enterprise is a narrative project.

\section{- Contingencies of Narrative Practice}

Active agency alters the quality of interview communication as well as its procedural sensibilities (see Gubrium \& Holstein, 1997, 2009a)—the ways in which we think about and evaluate what is and is 
not permissible within the interview encounter. We can sort these matters in terms of the contingent whats and hows of the interview noted earlier. One family of contingencies centers on the whats of interviewing, dealing with the substantive demands and circumstances of the research project. They provide interpretive signposts and resources for developing interview narratives. The eventual narrative is to some degree always already told in the kind of story prompted by the research project through the interviewer. From there, it is constructively elaborated in terms that resonate with the salient circumstances involved in and evoked by the interview process. These circumstances constitute the interview's narrative environment. As interviewing practices are deployed, participants are encouraged to narratively link the topics of interest to biographical particulars, taking account of the circumstantial contingencies of the interview process, producing a subject who both responds to and is affected by the narrative environment. Analysis must take these environments into consideration so that results are not merely coded without regard for context but are also examined for circumstantial and cultural resonances.

Another family of contingencies centers on the constructive hows of the interview process. Interview narratives develop within ongoing interaction. The interaction is not merely incidental but is a constitutive part of the meanings and accounts that emerge. In this context, it is not in the nature of narratives to simply flow forth, but instead, they are formulated and shaped in collaboration between the respondent and the interviewer. Participants continually construct and reflexively modify their roles in the exchange of questions and answers as the interview unfolds. The whats of the interview have to be interactionally put into place, managed, and sustained. The interplay between these hows and whatsbetween narrative work and its narrative environments, respectively-constitutes narrative practice (see Gubrium \& Holstein, 2009a).

\section{NARRATIVE WORK}

Eliot Mishler's (1986) discussion of empowering interview respondents has set a tone for the growing appreciation of narrative work in the interview context-the hows of the interview process.
Uncomfortable with the model of the interview as a controlled, asymmetric conversation dominated by the researcher (see Kahn \& Cannell, 1957; Maccoby \& Maccoby, 1954), Mishler examines the communicative assumptions and implications behind the standardized interview. His aim is to activate the interview by bringing the respondent more fully into the picture, to make the respondent an equal partner in the interview conversation.

Rather than modeling the interview as a form of stimulus and response, where the respondent is merely a repository of answers for the formalized questions asked by the interviewer, Mishler (1986) suggests that the interview encounter might more fruitfully be viewed as an interactional accomplishment. Noting that interview participants not only ask and answer questions in interviews but simultaneously engage in "speech activities," Mishler turns our attention to what participants do with words:

Defining interviews as speech events or speech activities, as I do, marks the fundamental contrast between the standard antilinguistic, stimulusresponse model and an alternative approach to interviewing as discourse between speakers. Different definitions in and of themselves do not constitute different practices. Nonetheless, this new definition alerts us to the features of interviews that hitherto have been neglected. (pp. 35-36)

The key phrase "discourse between speakers" directs us to the integral and inexorable speech activities that even survey interview participants engage in as they ask and answer questions (see Schaeffer \& Maynard, 2002), but that are treated as merely technical by survey researchers. Informed by conversation analytic sensibilities (see Sacks, 1992a, 1992b; Sacks, Schegloff, \& Jefferson, 1974), Mishler (1986) turns the reader to the discursive machinery evident in interview transcripts, which provides evidence of the way the interviewer and the respondent mutually monitor speech exchanges. Focused on these hows, Mishler discusses the way in which participants collaboratively construct their senses of the developing interview agenda. Mishler notes, for example, that even token responses by the interviewer, such as "Hmmm . . hmmm," can serve as a confirmatory marker that the respondent is on the right track for interview purposes, telling a pertinent story. The slightest or most mundane of speech acts 
is integral to an unfolding narrative. To eliminate them can, in effect, stop the conversation, hence the interview and the account. This observation points to the practical need for interview participants to be linguistically active and responsive, not just standardized and passive.

Mishler (1986) explains that each and every point in the series of speech exchanges that constitute an interview is subject to interactional work, activity aimed at producing interview data. This applies to both unstructured and standardized forms of interviewing. In contrast to the traditional asymmetric model of the interview, Mishler notes, in practice, that there is considerable communicative reciprocity and collaboration in interviewing:

The discourse of the interview is jointly constructed by interviewer and respondent.... Both questions and responses are formulated in, developed through, and shaped by the discourse between interviewers and respondents.... An adequate understanding of interviews depends on recognizing how interviewers reformulate questions and how respondents frame answers in terms of their reciprocal understanding as meanings emerge during the course of an interview. (p. 52)

As an alternative, Mishler (1986) advocates more open-ended questions, minimal interruptions of accounts, and the use of respondents' own linguistic formulations to encourage elaborations of the experiences in view. He urges researchers to consider ways in which interviewing can be activated, designed so that the respondent's voice comes through in greater detail as a way of highlighting respondent relevancies (see Holstein \& Gubrium, 2011).

This concern for voice privileges respondents' stories; experience, it is argued, takes meaningful shape as we narrate our lives (see, e.g., Chase, 2005; McAdams, 1993). We communicate experiences to each other in the form of stories. Encouraging elaboration, interviewers commonly use narrative devices such as "Go on," "Then what happened?" and so forth, prompting story-like formulations. In Mishler's (1986) view, it is difficult to imagine how an experience of any kind can be adequately conveyed except in such narrative terms.

Mishler (1986) recommends that we reconceptualize the research interview to "empower" respondents to tell their own stories. The word own is key here and will be of critical concern as we consider the issue of narrative ownership. Empowerment can be gotten by lessening interviewer control in the interview. According to Mishler, the goal is to hear the respondents' own voices and, in turn, obtain their own story (see Gubrium \& Holstein, 1997); empowerment, voice, and story are his leading concerns. But it is also important to explore the extent to which empowerment allows or provokes the respondent's own voice or the voicing of alternate subject positions to be expressed. In other words, when the respondent is actively encouraged to freely speak, whose voice do we hear? Does it assure us that we will hear the respondent's own story?

Conferring ownership, and by implication personal authenticity, on a particular narrative voice has major implications for what is taken to be the extent and purview of the narrative work involved. Mishler's (1986) sense of ownership locates authenticity within the narrator or storyteller, diminishing the role of the narrative-producing interaction and the broader narrative environment. This seems to contradict his call for "reciprocal understanding." If narrative analysis seeks the respondent's own voice and, as a result, his or her own story, as Mishler encourages, another form of passive image of the subject behind the respondent emerges, one that, in the final analysis, locates the true voice of the subject in the respondent's own vessel of answers. This effectively reappropriates passive subjectivity. The respondent is conceived as a subject who owns his or her story, who, on his or her own and under equalizing conditions, can and would narrate that story. The story is uniquely the respondent's in that only his or her own voice can articulate it authentically; any other voice or format detracts from this.

By resurrecting the subject as a vessel of answers, the respondent is reestablished as the ultimate repository of meaningful information, and the interviewer's job remains to extract that information. The process is now envisioned as interactively cooperative rather than interactionally controlled and directed. Nevertheless, as empowered or equalized as the interview conversation might be, the actual stories of respondents' lives are seen to emerge from a sort of internal repository.

While Mishler's (1986) strategy alters the shape of the discourse between speakers, it shortchanges the work that goes into producing authentic accounts. Narrative work does not stop with the 
extraction of the respondent's own stories but includes the integral production of authenticity, one common practical marker of which is equalized communication (see Gubrium \& Holstein, 2009a). Paul Atkinson (1997) is aware of this problem and recommends critical attention to the cultural conventions used to produce authentically personal stories. Writing about narrative analysis generally, but with clear implications for analyzing interview narratives, Atkinson argues,

The ubiquity of the narrative and its centrality ... are not license simply to privilege those forms. It is the work of anthropologists and sociologists to examine those narratives and to subject them to the same analysis as any other forms. We need to pay due attention to their construction in use: how actors improvise their personal narratives. ... We need to attend to how socially shared resources of rhetoric and narrative are deployed to generate recognizable, plausible, and culturally well-informed accounts.... What we cannot afford to do is to be seduced by the cultural conventions we seek to study. We should not endorse those cultural conventions that seek to privilege the account as a special kind of representation. (p. 341)

Atkinson (1997) is advocating a more fully interactional appreciation of interview accounts, especially those claimed to be personal narratives. Narrative work, from this perspective, includes any communicative activity involved in producing interview accounts: how interview participants work up adequate responses and what they attempt to accomplish in the process. Attention focuses on both how interview narratives are produced and the functions those narratives serve-in a word, what respondents do with the narratives (see Wittgenstein, 1953).

Ownership, and by implication personal authenticity, are established through the constructive voices of interacting narrative agents, which, as we'll illustrate shortly, also brings us to the whats of the matter. In practice, the idea of one's "own story" — which once was actually viewed as a methodological procedure and called the "own story method" (see Shaw, 1930/1966) — is not just a commendable research goal but is something participants themselves contend with as they move through the interview. They continuously and tentatively resolve the interactive problems of ownership as a way of sorting the possible subjectivities of an account and collaboratively proceed on that basis for practical communicative purposes. When a respondent such as a young wife and mother responds to a question about her parenting style, she might note that "it depends" on whether she is thinking (and speaking) in terms of the parenting manuals she conscientiously consults or in terms of her own mother's caution about sparing the rod and spoiling the child. One's own voice, in other words, depends on one's footing and related perspective on the matter, on whose voice is empowered and asserted in responding to the question. This is as much the respondent's doing as it is a matter of interviewer guidance.

An illustration from one of the authors' doctoral supervision duties shows the complexities of the narrative work involved in shifting footings and establishing narrative ownership. It also underscores the way in which the whats of narrative practice are intertwined with the hows of narrative work. Gubrium was serving on the dissertation committee of a graduate student who was researching substance abuse among pharmacists. The student was committed to allowing the pharmacists being interviewed to convey in their own words their experiences involving illicitly using drugs, seeking help for their habits, and going through rehabilitation. The graduate student had put in place a version of Mishler's (1986) empowerment strategy. He hoped to understand how those who "should know better" would describe what they did and explain what happened to them afterward.

When the interviews were completed, the interview data were analyzed thematically and presented in the dissertation as individual accounts of experience. Interestingly, several of the themes identified in the pharmacists' stories closely paralleled the familiar recovery themes of self-help groups such as Alcoholics Anonymous and Narcotics Anonymous (NA). As it turned out, many, if not all, of the pharmacists had participated in such recovery groups and evidently had incorporated these groups' ways of narrating the substance abuse and recovery experience into their "own" stories. For example, respondents spoke of the experience of "hitting bottom" and organized the stepwise trajectory of the recovery process in familiar NA terms in this case. Noting this, Gubrium raised the issue of the extent to which the interview material could be analyzed as the pharmacists' own stories as opposed to the stories of their 
recovery programs. At a doctoral committee meeting, he asked, "Whose voice do we hear when these pharmacists tell their stories? Their own or NA's?" The question, in effect, asked whether the stories belonged to the individuals being interviewed or to the organizations that promulgated their discourse.

An equalized and unstructured interview environment does not so much guarantee narrative authenticity as help make its accomplishment and sources more visible. It opens to view the complex work and sources of subject positioning in storytelling (see Koven, in press). For example, in the best of interview circumstances, does a 50-year-old man offer the opinions of a professional at the height of his career, or might his voice be that of a husband and father reflecting on what he missed in family life along the way? Or will he speak as a church elder, a novice airplane pilot, or the "enabling" brother of an alcoholic at different points of the interview? All of these might be possible, given the range of subject positions that could underpin the accounts the man offers in response to interview questions. Each has multiple bases for authenticity. In practice, respondent subjectivity emerges out of the give-and-take of the interview process, even while the researcher might hope for a particular form of agency or footing to emerge out of an interview format designed to explore a specific research topic.

In contrast to the unwitting ways in which the preceding pharmacists' accounts drew on alternate subject positions, interview participants can also be openly strategic about this practice, which is the reason why both the hows and the whats of narrative practice must be examined. Consider a passing comment that might be made by a father being interviewed about parenting practices. Following a question asking him to place himself along a fivepoint continuum of parenting styles, from being an authority figure at one end to being a friend at the other, the man responds to another interview item:

I figure that ... what did you say?... I can be "friendly" [gestures quotation marks with his hands] when I have to and that usually works, unless they [his children] really get wound up, then another father comes out.

The inserted question "What did you say?" references a possible subject position articulated earlier by the interviewer, the implication being that, in the give-and-take of the interview, participants jointly figured the father's narrative positions and resulting interview data.

Verbal prefaces are frequently used to signal shifts in subjectivity, something often ignored in interview research. The phrases "to put myself in someone else's shoes" and "to put on a different hat" are speech acts that voice shifts in footing. For example, in an interview study of nurses' opinions on the qualities of good infant care, we probably wouldn't be surprised to hear a respondent say something like, "That's when I have my RN [registered nurse] cap on, but as a mother, I might tell you a different story." Some respondents are didactic in giving voice to alternative subject positions and their respective points of view, as when a respondent prefaces a response with "What I mean is ... from the point of view of a ..." or "Let me explain what I mean... it depends on whose shoes you're wearing, doesn't it?" Such phrases are not interview debris but skillfully do things with words, in this case conveying an important and persistent complication of interview subjectivity.

But things are seldom this straightforward. An interview, for example, might start with the presumption that a father or a mother is being interviewed, which the interview's introductions appear to confirm. But there is no guarantee that these subject positions will remain constant throughout. This isn't often evident in so many words or comments. Indeed, the possibility of an unforeseen change in subjectivity might not be broached, if broached at all, until the very end of the interview, when a respondent remarks, "Yeah, that's the way all of us who were raised down South do with our children," making it unclear who or what exactly has been providing responses to the interview's questions, this individual parent or her region of the country.

The work of establishing subject position and voice also implicates the interviewer. Who, after all, is the interviewer to the respondent? How will the interviewer role fit into the conversational matrix? For example, respondents in debriefings might comment that an interviewer sounded more like a company man than a human being or that one interviewer made the respondent feel that the interviewer was "just an ordinary person, like myself." This raises the possibility that the respondent's perceived subject position, and by implication the respondent's "own" story, is constructed out of the unfolding interpersonal sentiments of the interview participants. 
If this isn't complicated enough, imagine what the acknowledgement of multiple subject positions does to the concept of sample size. To decompose the designated respondent into his or her subject positions raises the possibility that any sample unit or set of units can expand or contract in size in the course of the interview, increasing or decreasing the sample $n$ in the process. Treating subject positions and their associated voices seriously, we might find that what we took to be a single interview, in practice, is an interview with several subjects, whose particular identities may only be partially, if at all, clear. To be satisfied that one has completed an empowered interview with a single respondent and to code it as such because it was conducted in a context of equalitarian exchange is to be rather cavalier about narrative practice.

All of this is reason enough for some researchers to approach the interview as a set of positions and accounts that are continuously accomplished. In standardized interviewing, one needs to conclusively settle on the matter of who the subject behind the respondent is, lest it be impossible to know to which population generalizations can be made-a dubious goal in the context of practice. A respondent who shifts the subjectivity to whom she is giving voice poses dramatic difficulties for the kind of generalization survey researchers aim for. Varied parts of a single completed interview, for example, would have to be coded as the responses of different subjects and be generalizable to different populations, which would be a conceptual, if not just a procedural, nightmare.

\section{NARRATIVE ENVIRONMENTS}

If they are not straightforwardly owned by individuals, where do interview narratives come from? This turns us to the whats of the matter and their complications, broached in our pharmacist illustration. It was evident in the previous discussion of the pharmacist drug abuse research that respondents made use of a very common notion of recovery in today's world, one that has percolated through the entire troubles treatment industry (Gubrium \& Holstein, 2001). Does this industry, or other institutions dealing with human experiences, offer an answer to the question?

Erving Goffman's (1961) exploration of what he called "moral careers" provides a point of departure for addressing this. Goffman was especially concerned with the moral careers of stigmatized persons such as mental patients, but his approach is broadly suggestive. In his reckoning, each of us has many available identities and associated ways of accounting for our actions. Goffman described the prepatient, patient, and postpatient selves that individuals constructed, along with others, on their way into and out of mental hospitals. He referred to this trajectory of identities as a moral career because it had implications for the selfrepresentation of those concerned, both the individual patients in question and those who interacted with them. The identities were moral because they related significantly to choices made about who one was, is now, and would be, implicating the appropriateness of the accounts conveyed in the process.

According to Goffman (1961), individuals obtain narrative footing as they move through the various moral environments that offer pertinent recipes for identity. A mental hospital, he noted, provides the individuals it serves with particular selves, which includes ways of storying who one is, one's past, and one's future. The moral environment of the mental hospital also provides others, such as staff members, acquaintances, and even strangers, with parallel footing, such as what to expect from and how to respond to patients as they move along the trajectory. As far as stories are concerned-both our own and those of others-moral environments are also narrative environments.

Goffman's (1961) analysis of moral careers focused on what he called "total institutions," environments whose narrative options are limited and engulf the self. What Everett Hughes (1942/1984) calls "going concerns" expand moral careers and their narrative options to the world at large, to the many and varied social locations, not just formal organizations, that specify pertinent identities and ways of accounting for ourselves. It was Hughes's way of emphasizing that institutions are not just formally mandated and, more important in practice, are not fixed establishments but that considerable narrative work keeps them going, to put it in our terms. How we story our lives is as varied as the narrative options available. Going concerns are a virtual landscape of narrative possibilities, stunningly complicating our moral careers and their accounts.

From the myriad formal organizations in which we work, study, play, and recover, to the countless informal associations and networks to which we otherwise attend, to our affiliations with racial, ethnic, 
and gendered groupings, we engage in a panoply of going concerns on a daily basis. Taken together, they set the conditions of possibility (Foucault, 1979) for narrative footing-for who and what we could possibly be. Many going concerns explicitly structure or reconfigure personal identity. Human service agencies, for example, readily delve into the deepest enclaves of the self to ameliorate personal ills, with the aim of re-storying our lives. Self-help organizations seem to crop up on every street corner, and self-help literature beckons us from the tabloid racks of most supermarkets and the shelves of every bookstore. "Psychobabble" on radio and TV talk shows constantly prompts us to formulate (or reformulate) our stories, aiming to give voice to the selves we do or should live by. Interviewing without these whats in view shortchanges the extensive communicative apparatus that prompts and supports accounts.

Narrative environments not only feed personal accounts but are also a source of socially relevant questions that interviewers pose to respondents. To the extent that those who conduct large-scale surveys are sponsored by the very agents who formulate applicable discourses such as recovery trajectories, the collaborative production of the respondent's own story is shaped, for better or worse, in agreements and markets well beyond the give-and-take of the interview conversation-such are the proprietary subjectivities of individual accounts in a world of going concerns (Gubrium \& Holstein, 2000).

This observation returns us to the interview society. The research context is not the only place in which we are asked interview questions and are expected to respond in turn with opinions. Virtually all going concerns are in the interviewing business; they construct and marshal the subjects they need to do their work. Each provides a communicative context for narrative practice, for the collaborative production of the moral equivalents of respondents and interviewers. Medical clinics deploy interviews and, in the process, assemble doctors, patients, and their illnesses (see Zoppi \& Epstein, 2002). Personnel officers interview job applicants and collect information that forms the basis for selection decisions (see Latham \& Millman, 2002). Therapists of all stripes continue to interview as they have for decades and assemble narrative plots of illness experiences, which form the basis for further, rehabilitative interviewing (see Frank, 1995; Kleinman, 1988; Mattingly, 1998; Miller, de Shazer, \& De Jong, 2002). The same is true for schools, forensic investigation, and journalistic interviewing, among the broad range of concerns that enter our lives and help shape our stories (see Altheide, 2002; Gabriel, 2000; McKenzie, 2002; Tierney \& Dilley, 2002).

As the interview society expands the institutional auspices of interviewing well beyond the research context, it would be a rather narrow perspective on the interview to limit ourselves to research environments. The research interview is only one of the many sites where subjectivities and the voicing of individual experience are storied. These going concerns can't be considered to be independent of each other. As our pharmacist illustration suggested, the narrative environments of therapy and recovery can be brought directly into the research interview, serving to commingle a spectrum of institutional voices.

Our understandings of subjectivity and voice are varied and deepened as new formats for interviewing are developed. These formats are themselves going concerns, providing distinctive narrative environments. The group interview, for example, can be a veritable swirl of subject positions and opinion construction, as participants share and make use of story material from a broader range of narrative resources than a single interview might muster on its own. Life story and oral history interviews extend biographical construction through time, which can be amazingly convoluted when compared with the often detemporalized information elicited in cross-sectional surveys (see Atkinson \& Coffey, 2002; Cándida-Smith, 2002). The in-depth interview extends experience in emotional terms, affectively elaborating subjectivity by constructing it ever more deeply within experience (see Johnson, 2002).

\section{- It's Like Jazz}

To guard against overdetermining the role of either narrative environments or narrative work in the production of interview accounts, it is important to emphasize that the practice of interviewing refracts, but does not reproduce, the narratives proffered by going concerns. Interview participants themselves are biographically active in shaping how received subjectivities are put to use in the interview process. While institutional auspices provide resources for both asking questions and providing answers, prescribe possible roles for interview participants, and 
privilege or marginalize certain accounts, these resources and roles are not automatically adopted and reproduced in practice. If participants are accountable to particular circumstances, such as conducting social-scientific research, completing job interviews, or interrogating suspects in criminal procedures, they borrow from the variety of narrative resources available to them. They are more "artful" (Garfinkel, 1967) than mechanistic in managing their roles and giving voice to experience.

The pharmacist example is a case in point. While these were formal research interviews, it was evident that respondents were interpolating their stories in NA recovery terms. They drew from their experiences in recovery groups to convey to the interviewer what it felt like to be "taken over" by controlled substances. As noted earlier, several respondents used the familiar metaphors of "hitting bottom" and " 12 steps" to convey a trajectory for the experience. But the respondents weren't simply mouthpieces for NA; they put individual spins on NA terminology. "Hitting bottom" could mean different things to the respondents, depending on biographical particulars. How hitting bottom narratively figured in one respondent's experience was no guarantee of how it figured in another's. Hitting bottom for the tenth time, for instance, could have different moral contours from hitting bottom for the first (or only) time.

As in producing jazz, themes and improvisation are the hallmarks of narrative practice. Interview narratives are artfully assembled, discursively informed, and circumstantially conditioned. Because the stories we live by refract a world of competing going concerns, they do not uniformly reproduce a collection of accounts. The interplay of narrative work and narrative environments-the constructive hows and substantive whats of the matter-provides interviews with a discernable range of possibilities for asking and responding to questions about what we are and what our worlds are like. In this scheme of things, the interview is far more than a technical way of extracting information. If the interview is now among our most commonplace and conventional means of gathering experiential information, the voices we hear within it represent a dispersed ownership, endless senses of who and what we could be, and variegated perspectives on our social worlds.

The relationship between this information and society is complex. In one sense, it derives from individualized accounts conveyed in diverse voices, positioned in different locations in the empirical landscape. The democratization of opinion assures us that each and every one of us counts in the grander scheme of public opinion. But in a second sense, democratization is too simple a notion. It ignores the social forces and cultural frameworks that inform the whats and hows of individualized accounts. While the mechanism of data gathering in interviews and the analysis of responses draw from individualized testimony, we now realize that the modern temper that made this possible was always already up against the expanding discourses used to articulate what we think, how we feel, and how we expect to act. The increasing medicalization of experience, for example, has transformed much of this into accounts of illness and health, and lately of fitness. The once healthy, "chubby" baby is now subject to the gaze and resulting accounts of the medicalization of body weight, portending a future of illness or obesity for the person the child might become. In the 1980s, interview accounts of family members' experiences of caring for demented elderly loved ones gradually turned from accounts of caring for the normal confusion and senility of late life to the sickness of Alzheimer's disease and the hope for recovery (Gubrium, 1986). These changing whats of individual accounts drawn from interviews are immersed in new and emerging discourses of experience.

Complexity is asserted in a third sense because society is not merely a discursive template for individual articulation. While the shared themes of dominant and changing discourses provide narrative resources for asking interview questions and responding to them, the questions asked in interviews and the responses to them vary in their own right. They draw on biographical particulars in the context of specific research questions to collaboratively construct individualized articulations of shared understandings. The hows of the matter are, again like jazz, improvisational. Yes, there are discursive themes, but these are assembled and constructed in relationship to the narrative improvisations of biography, perspective, interests, and the immediate pertinences of the process.

The analogy to jazz encourages us to be ethnographically sensitive in conducting interview research (see Gubrium \& Holstein, 2009a). The transformation of interview subjectivity has reached a point where the whats of interview questions and responses can no longer be left to the quantifying devices of traditional survey sensibilities. They must be 
extended to an understanding of the ways discourse and going concerns relate to individual accounts. The same sensibility encourages us to move beyond the turn-taking hows of interview practice. The hows can no longer be left to the everyday tool-identifying devices of conversation analysis. They must be extended to include the broader constructive hows of narration as it plays out in discursive practice (Gubrium \& Holstein, 2009a; Holstein \& Gubrium, 2000). Methods of analysis are accordingly informed by a model of narratively active subjectivity (see Cerwonka \& Malkki, 2007).

\section{$\checkmark$ References}

Adler, P. A., \& Adler, P. (2002). The reluctant respondent. In J. F. Gubrium \& J. A. Holstein (Eds.), Handbook of interview research (pp. 515-536). Thousand Oaks, CA: Sage.

Alasuutari, P. (1998). An invitation to social research. London, England: Sage.

Altheide, D. L. (2002). Journalistic interviewing. In J. F. Gubrium \& J. A Holstein (Eds.), Handbook of interview research (pp. 411-430). Thousand Oaks, CA: Sage.

Atkinson, P. (1997). Narrative turn or blind alley? Qualitative Health Research, 7, 325-344.

Atkinson, P., \& Coffey, A. (2002). Revisiting the relationship between participant observation and interviewing. In J. F. Gubrium \& J. A. Holstein (Eds.), Handbook of interview research (pp. 801-814). Thousand Oaks, CA: Sage.

Atkinson, P., \& Silverman, D. (1997). Kundera's immortality: The interview society and the invention of the self. Qualitative Inquiry, 3, 304-325.

Bamberg, M. (2006). Stories: Big or small, why do we care? Narrative Inquiry, 16, 139-147.

Benney, M., \& Hughes, E. C. (1956). Of sociology and the interview. American Journal of Sociology, 62, 137-252.

Briggs, C. (1986). Learning how to ask. Cambridge, England: Cambridge University Press.

Briggs, C. L. (2007). Anthropology, interviewing, and communicability in contemporary society. Current Anthropology, 48, 551-580.

Cándida-Smith, R. (2002). Analytic strategies for oral history interviews. In J. F. Gubrium \& J. A. Holstein (Eds.), Handbook of interview research (pp. 711-732). Thousand Oaks, CA: Sage.

Cerwonka, A., \& Malkki, L. (2007). Improvising theory: Process and temporality in ethnographic fieldwork. Chicago, IL: University of Chicago Press.
Chase, S. (2005). Narrative inquiry: Multiple lenses, approaches, voices. In N. Denzin \& Y. Lincoln (Eds.), The SAGE handbook of qualitative research (3rd ed., pp. 651-679). Thousand Oaks, CA: Sage.

Chase, S. (2011). Narrative inquiry: Still a field in the making. In N. Denzin \& Y. Lincoln (Eds.), The SAGE handbook of qualitative research (4th ed.). Thousand Oaks, CA: Sage.

Cicourel, A. (1964). Method and measurement in sociology. New York, NY: Free Press.

Cicourel, A. V. (1974). Theory and method in a study of Argentine fertility. New York, NY: Wiley.

Clandinin, D. (Ed.). (2007). Handbook of narrative inquiry. Thousand Oaks, CA: Sage.

Conrad, F. G., \& Schober, M. F. (2008). New frontiers in standardized survey interviewing. In S. N. Hesse-Biber \& P. Leavey (Eds.), Handbook of emergent methods (pp. 173-188). New York, NY: Guilford Press.

Denzin, N. K., \& Lincoln, Y. S. (Eds.). (2005). The SAGE handbook of qualitative research ( $3 \mathrm{rd}$ ed.). Thousand Oaks, CA: Sage.

Denzin, N. K., \& Lincoln, Y. S. (Eds.). (2011). The SAGE handbook of qualitative research (4th ed.). Thousand Oaks, CA: Sage.

Dreyfus, H. L., \& Rabinow, P. (1982). Michel Foucault: Beyond structuralism and hermeneutics. Chicago, IL: University of Chicago Press.

Foucault, M. (1973). Madness and civilization. New York, NY: Vintage Books.

Foucault, M. (1975). Birth of the clinic. New York, NY: Vintage Books.

Foucault, M. (1977). Discipline and punish. New York, NY: Vintage Books.

Foucault, M. (1978). The history of sexuality: An introduction (Vol. 1). New York, NY: Vintage Books.

Foucault, M. (1979). Discipline and punish: The birth of the prison. New York, NY: Vintage Books.

Foucault, M. (1988). Technologies of the self (L. H. Martin, H. Gutman, \& P. H. Hutton, Eds.). Amherst: University of Massachusetts Press.

Foucault, M. (1991). Governmentality (R. Braidotti, Trans., \& C. Gordon, Rev.). In G. Burchell, C. Gordon, \& P. Miller (Eds.), The Foucault effect: Studies in governmentality (pp. 87-104). Chicago, IL: University of Chicago Press.

Fowler, F. J., \& Mangione, T. W. (1990). Standardized survey interviewing. Newbury Park, CA: Sage.

Frank, A. (1995). The wounded storyteller. Chicago, IL: University of Chicago Press.

Gabriel, Y. (2000). Storytelling in organizations: Facts, fictions, and fantasies. Oxford, England: Oxford University Press.

Garfinkel, H. (1967). Studies in ethnomethodology. Englewood Cliffs, NJ: Prentice Hall. 
Garland, D. (1997). "Governmentality" and the problem of crime. Theoretical Criminology, 1, 173-214.

Goffman, E. (1961). Asylums. New York, NY: Doubleday.

Gorden, R. L. (1987). Interviewing: Strategy, techniques, and tactics. Homewood, IL: Dorsey Press.

Gubrium, J. F. (1986). Oldtimers and Alzheimer's: The descriptive organization of senility. Greenwich, CT: JAI Press.

Gubrium, J. F., \& Holstein, J. A. (1995). Qualitative inquiry and the deprivatization of experience. Qualitative Inquiry, 1, 204-222.

Gubrium, J. F., \& Holstein, J. A. (1997). The new language of qualitative method. New York, NY: Oxford University Press.

Gubrium, J. F., \& Holstein, J. A. (2000). The self in a world of going concerns. Symbolic Interaction, 23, 95-115.

Gubrium, J. F., \& Holstein, J. A. (Eds.). (2001). Institutional selves: Troubled identities in a postmodern world. New York, NY: Oxford University Press.

Gubrium, J. F., \& Holstein, J. A. (2002). From the individual to the interview society. In J. F. Gubrium \& J. A. Holstein (Eds.), Handbook of interview research (pp. 3-32). Thousand Oaks, CA: Sage.

Gubrium, J. F., \& Holstein, J. A. (2009a). Analyzing narrative reality. Thousand Oaks, CA: Sage.

Gubrium, J. F., \& Holstein, J. A. (2009b). The everyday work and auspices of authenticity. In P. Vannini \& J. P. Williams (Eds.), Authenticity in culture, self, and society (pp. 121-138). Surrey, England: Ashgate.

Holstein, J. A., \& Gubrium, J. F. (1995). The active interview. Thousand Oaks, CA: Sage.

Holstein, J. A., \& Gubrium, J. F. (2000). The self we live by: Narrative identity in a postmodern world. New York, NY: Oxford University Press.

Holstein, J. A., \& Gubrium, J. F. (2011). Animating interview narratives. In D. Silverman (Ed.), Qualitative research: Theory, method, and practice (3rd ed., pp. 149-167). London, England: Sage.

Hootkoop-Steenstra, H. (2000). Interaction and the standardized survey interview. Cambridge, England: Cambridge University Press.

Hughes, E. C. (1984). The sociological eye: Selected papers. Chicago, IL: Aldine. (Original work published 1942)

Hyvärinen, M. (2008). Analyzing narratives and storytelling. In P. Alasuutari, L. Bickman, \& J. Brannen (Eds.), The SAGE handbook of social research methods (pp. 447-460). London, England: Sage.

Johnson, J. M. (2002). In-depth interviewing. In Handbook of interview research (J. F. Gubrium \& J. A. Holstein, Eds.). Thousand Oaks, CA: Sage.

Kahn, R. L., \& Cannell, C. F. (1957). The dynamics of interviewing: Theory, technique, and cases. New York, NY: Wiley.

Kleinman, A. (1988). The illness narratives. New York, NY: Basic Books.
Koven, M. (in press). Speaker role analysis of personal narratives. In J. A. Holstein \& J. F. Gubrium (Eds.), Varieties of narrative analysis. Thousand Oaks, CA: Sage.

Kvale, S. (1996). InterViews: An introduction to qualitative research interviewing. London, England: Sage.

Latham, G. P., \& Millman, Z. (2002). Context and the employment interview. In J. F. Gubrium \& J. A. Holstein (Eds.), Handbook of interview research (pp. 473-486). Thousand Oaks, CA: Sage.

Linde, C. (1993). Life stories: The creation of coherence. New York, NY: Oxford University Press.

Maccoby, E. E., \& Maccoby, N. (1954). The interview: A tool of social science. In G. Lindzey (Ed.), Handbook of social psychology (Vol. 1, chap. 12). Cambridge, England: Addison-Wesley.

Mattingly, C. (1998). Healing dramas and clinical plots: The narrative structure of experience. New York, NY: Cambridge University Press.

Mayhew, H. (1851). London labour and the London poor (Vol. 1). New York, NY: Dover.

McAdams, D. (1993). The stories we live by: Personal myths and the making of the self. New York, NY: Guilford Press.

McKenzie, I. K. (2002). Forensic investigative interviewing. In J. F. Gubrium \& J. A. Holstein (Eds.), Handbook of interview research (pp. 431-452). Thousand Oaks, CA: Sage.

Miller, G., de Shazer, S., \& De Jong, P. (2002). Therapy interviewing. In J. F. Gubrium \& J. A. Holstein (Eds.), Handbook of interview research (pp. 384-410). Thousand Oaks, CA: Sage.

Miller, J. (1993). The passion of Michel Foucault. New York, NY: Doubleday.

Mishler, E. (1986). Research interviewing: Context and narrative. Cambridge, England: Harvard University Press.

Morgan, D. L. (2002). Focus group interviewing. In J. F. Gubrium \& J. A. Holstein (Eds.), Handbook of interview research (pp. 141-160). Thousand Oaks, CA: Sage.

Platt, J. (2002). The history of the interview. In J. F. Gubrium \& J. A. Holstein (Eds.), Handbook of interview research (pp. 33-54). Thousand Oaks, CA: Sage.

Polkinghorne, D. E. (1988). Narrative knowing and the human sciences. Albany, NY: SUNY Press.

Polkinghorne, D. E. (1995). Narrative configuration in qualitative analysis. In J. A. Hatch \& R. Wisniewski (Eds.), Life history and narrative (pp. 5-23). London, England: Falmer Press.

Riesman, D., \& Benney, M. (1956). Asking and answering. Journal of Business of the University of Chicago, 29, 225-236.

Riessman, C. K. (2008). Narrative methods for the human sciences. Thousand Oaks, CA: Sage.

Rose, N. (1990). Governing the soul: The shaping of the private self. London, England: Routledge.

Rose, N. (1997). Inventing ourselves: Psychology, power, and personhood. Cambridge, England: Cambridge University Press. 
Sacks, H. (1992a). Lectures on conversation (Vol. 1). Oxford, England: Wiley-Blackwell.

Sacks, H. (1992b). Lectures on conversation (Vol. 2). Oxford, England: Wiley-Blackwell.

Sacks, H., Schegloff, E. A., \& Jefferson, G. (1974). A simplest systematics for the organization of turn taking for conversation. Language, 40, 696-735.

Schaeffer, N. C., \& Maynard, D. W. (2002). Standardization and interaction in the survey interview. In J. F. Gubrium \& J. A. Holstein (Eds.), Handbook of interview research (pp. 577-602). Thousand Oaks, CA: Sage.

Shaw, C. R. (1966). The jack-roller: A delinquent boy's own story. Chicago, IL: University of Chicago Press. (Original work published 1930)

Silverman, D. (1993). Interpreting qualitative data. London, England: Sage.
Silverman, D. (1997). Qualitative research: Theory, method, and practice. London, England: Sage.

Terkel, S. (1972). Working. New York, NY: Avon.

Tierney, W. G., \& Dilley, P. (2002). Interviewing in education. In J. F. Gubrium \& J. A. Holstein (Eds.), Handbook of interview research (pp. 453-472). Thousand Oaks, CA: Sage.

Warren, C. A. B., \& Karner, T. (2005). Discovering qualitative methods. Los Angeles, CA: Roxbury.

Weiss, R. S. (1994). Learning from strangers. New York, NY: Free Press.

Wittgenstein, L. (1953). Philosophical investigations. New York, NY: Macmillan.

Zoppi, K. A., \& Epstein, R. M. (2002). Interviewing in medical settings. In J. F. Gubrium \& J. A. Holstein (Eds.), Handbook of interview research (pp. 355-384). Thousand Oaks, CA: Sage. 